\title{
PROCES TWORZENIA SIE KOŚCIOŁA I JEGO KOLEGIALNOŚĆ W ŚWIETLE ZASADY MARYJNEJ
}

\section{THE CHURCH FORMATION PROCESS AND ITS COLLEGIALITY IN THE LIGHT OF THE MARIAN PRINCIPLE}

The article shows a five-step process of the formation of the Church: 1. the extra-temporal idea of God the Father, 2. her development in the Old Covenant, 3. establishing by Jesus, 4. fulfilling herself from the Pentecost, and 5. aiming at an eschatological fullness - which is a prospect to prove the thesis that the departure from the Marian principle or even its partial weakening leads to the impoverishment of her entire divine-human reality. Consequently, there is a disturbance of the Church's hierarchical structure and thus improper functioning of collegiality and the weakening of the Church's credibility and missionary nature. Without this tension between the Marian principle and Peter's principle, the Christian community is not fully functioning in its missionary activity either. This was pointed out not only by Paul VI in his exhortation Evangelii nuntiandi as early as 1975, but also recently by Francis in the 2013 exhortation Evangelii gaudium. The Marian principle in the Church becomes an inalienable guarantee of proper evangelization in the modern world. Correctly constructed ecclesiology is not disconnected, not only from Trinitology, Christology, pneumatology but also from Mariology.

Key words: formation of the Church, ecclesiology, collegiality, Mariology, evangelization. 


\section{Cel i założenia}

Niniejsze przedłożenie jest próbą udowodnienia tezy, iż odejście od zasady Maryjnej w Kościele czy też już nawet jej częściowe osłabienie, prowadzi do zubożenia jego całej Bosko-ludzkiej rzeczywistości i tym samym zachwiania jego strukturą hierarchiczną, a w konsekwencji do anemicznego funkcjonowania jego kolegialności i osłabienia kościelnej wiarygodności.

Przywołamy najpierw obrazy Kościoła - zwłaszcza opierając się na przesłankach biblijnych - w jego pięciu fazach powstawania, próbując pokazać w każdej fazie zasadę Maryjną, aby przejść do przedstawienia współczesnych jego ujęć, co ma miejsce zarówno w propozycjach teologicznych, jak i w oficjalnym nauczaniu magisterialnym. Takie tło stanie się miarodajną podstawą do omówienia kolegialności jako sposobu sprawowania władzy w Kościele. W końcowej części przejdziemy do wyprowadzenia wniosków odnośnie do stosowania zasady Maryjnej i jej wpływu na hierarchiczną kompozycję eklezjalną. Trzeba bowiem pamiętać, iż o Kościele mówimy wówczas odpowiedzialnie, kiedy naczelną kwestią jest pytanie o Boga i o poznanie Jego ludzkiej obecności w Jezusie Chrystusie, który narodził się z Maryi Dziewicy przez działanie Ducha Świętego.

Temat procesu tworzenia się Kościoła i jego kolegialność w świetle zasady Maryjnej można też przeanalizować od strony metodologicznej. Uzasadnieniem takiego podejścia jest zmiana metody, co miało miejsce po Soborze Watykańskim II, powodując znaczący spadek publikacji z zakresu mariologii i było równoczesnym odsłonięciem niedomagań w zakresie metodologii. W pierwszym dziesięcioleciu po Vaticanum II wielu przedstawicieli przedsoborowej mariologii miało poważne trudności, aby przejść od metody spekulatywnej do metody pozytywnej. Nie mogli sobie poradzić z wprowadzeniem nauki o Matce Chrystusa w chrystologię, eklezjologię, hamartiolgię, sakramentologię, pneumatologię czy eschatologię. Jednakże w naszym opracowaniu pozostaniemy przy nadmienionym już aspekcie formalnym, choć rekonstrukcja stosowanych metod w eklezjologii i ujawnienie ich słabości mogłaby okazać się dość interesująca i nawet bardziej przemawiająca na korzyść dowartościowania zastosowania zasady Maryjnej dla eklezjologii i tym samym dla większej poprawności rozumienia i praktykowania kolegialności ${ }^{1}$.

\section{Biblijne etapy powstawania Kościoła oraz figura Maryi}

Przejdźmy teraz do podstaw w Piśmie Świętym, jakie dają właściwe umocowanie eklezjogenezy tak starotestamentalnej, jaki nowotestamentowej.

Por. W. Życiński, Jaka mariologia na polskiej drodze maryjnej dzisiaj, [w:] Na polskiej drodze maryjnej, red. A. Gąsior, J. Królikowski, Częstochowa - Pasierbiec 2007, s. 139-151. 
Spróbujemy przywołać biblijne kobiety, które w sensie typicznym są zapowiedzią i figurą Maryi z Nazaretu, Matki Jezusa. Uwzględnimy najpierw okres Starego Testamentu, bo nie do końca wiadomo, dlaczego tak często pomijana jest eklezjogeneza starotestamentalna. A jeśli jest już odwołanie do Starego Testamentu w odniesieniu do wykształcania się Kościoła, to jest to czynione dość powierzchownie i parcjalnie.

Wyróżniamy pięć etapów powstawania Kościoła: 1. Pozaczasowa idea Boga Ojca, 2. Konstytuowanie w Starym Przymierzu, 3. Ustanowienie przez Jezusa, 4. Spełniający się od Zesłania Ducha Świętego oraz 5. Zdążający do eschatologicznej pełni².

Dynamika powstawania Kościoła ujawnia się w całej rozciągłości, jeśli odwołamy się najpierw do idei Boga Ojca w Starym Testamencie, który w momencie grzechu pierwszych ludzi, wychodzi z propozycją zawiązania wspólnoty jeszcze bardziej doskonałej i ostatecznej niż wspólnota kreacji. Wynikiem stworzenia jest otrzymanie przez człowieka obrazu i podobieństwa Bożego (imago et similitudo Dei), co wyraża się w rozumności, wolitywności oraz duchowości istoty ludzkiej. Wyrwanie się Ewy i Adama ze związków ze swoim Stworzycielem, prowadzi do tego, iż Bóg chce teraz zaprosić ich do wspólnoty jeszcze bardziej doskonalszej, tj. do wspólnoty rodzinnej, aby stali się Jego przybranymi dziećmi. Odniesienie do $\mathrm{Rdz}$ 3, 15 nabiera w tym świetle znaczenia nie tylko soteriologicznego, ale i eklezjologicznego. Poziom kreacji będzie zastąpiony innym poziomem egzystencji, a mianowicie stanem trwałego odkupienia, jakiego dokona w swoim posłuszeństwie w Duchu Świętym Jednorodzony Syn Boży. Na etapie pozaczasowej idei Kościoła u Boga Ojca figurą Maryi jest Ewa. W Rdz 3,15 odnajdujemy zapowiedź zwycięstwa, które będzie zwycięstwem potomstwa biblijnej Ewy nad potomstwem szatana. Jest to pierwsza Dobra Nowina (Protoewangelia), w którą wpisana jest Maryja jako Matka właściwego Potomka. Tak oto Ewa $z$ ogrodu stworzenia staje się zapowiedzią Maryi z ogrodu odkupienia ${ }^{3}$.

Przesuńmy się do drugiego etapu wykształcania się Kościoła, którym jest czas jego konstytuowania się w Starym Przymierzu. Ten etap rozciąga się od momentu zwołania Izraela (kahal Jahwe) jako Ludu Bożego Starego Przymierza do chwili powstania z jego części nowego Ludu w krwi Jezusowej Nowego Przymierza. Należy się tutaj odwołać do przymierza Jahwe z Abrahamem (por. $\operatorname{Rd} z$ 17, 1-7). Istotnym elementem kształtowania się Hebrajczyków jako Ludu Bożego była ich 400-letnia niewola egipska, kiedy ich prześladowanie wyznaczało im odmienność narodową i kierowało w stronę monoteizmu. Przymierze zawarte z Mojżeszem na Górze Synaj to oficjalne i prawne przyjęcie zobowiązań

Por. A. Napiórkowski, Proegzystencja Kościoła, Kraków 2018, s. 65-93.

Por. tamże, s. 68-70. 
między Jahwe i Izraelem. Objawienie się Boga na Górze Synaj miało decydujące znaczenie dla kwalifikacji nowej samoświadomości Hebrajczyków.

Opanowanie Kanaanu przez Izraelitów pod wodzą Jozuego, rozpoczyna okres sędziów, trwający od 1200 roku do 1025 roku przed Chrystusem. Dla eklezjogenezy starotestamentalnej ten etap nie jest aż tak ważny, ale warto zwrócić uwagę na fakt, że sędziami byli zarówno mężczyźni, jak i kobiety, np. Debora, a jej pieśń uchodzi za klejnot poezji biblijnej. Działanie Debory jest autentyczne wyzwalające, ponieważ jest to owoc wyjątkowej relacji, jaka łączyła ją z Bogiem Izraela. Bez wiary jej słowo nie byłoby prorocze, a jej przewodzenie nie miałoby dostatecznej legitymacji.

Wynikiem narastającego monoteizmu wśród Izraela jest budowa przez Salomona Świątyni Jerozolimskiej - będącej zapowiedzią Kościoła Chrystusa - dla jedynego Boga Izraela, jakim jest Jahwe. Formowanie się Ludu Starego Przymierza zaznacza się też we wznoszeniu synagog i w jej funkcjach. Ponieważ od zburzenia Świątyni Jerozolimskiej w roku 587 / 586 p.n.e. i deportacji babilońskiej brakuje jednego ośrodka religijnego, Żydzi w swoich miejscach rozproszenia, gromadzą się w nowych domach modlitwy, jakimi są synagogi. Powoduje to również przejście od formy kultu świątynnego do kultu rabinackiego. Można zatem dostrzec zmiany w religijności Żydów, naznaczonych wyborem w Abrahamie, a następnie potwierdzonym i rozszerzonym w przymierzu z Mojżeszem ${ }^{4}$.

Na konstytuowanie się Kościoła w Starym Testamencie miały wpływ naturalnie inne przymierza (np. z Gedeonem), niewole i deportacje. Istotnym elementem tego etapu jest „Reszta Izraela przez łaskę”, o której uczą prorocy: Izajasz, Ezechiel, Jeremiasz. „Reszta przez łaskę” odsłania nam przechodzenie Izraela $z$ biologicznego poziomu (urodzenie, obrzezanie, Tora, prawo, 613 przykazań halachy, ryty) na duchowy poziom (wiary, łaski). Stary Testament objawia nam jednoczenie się Jahwe z człowiekiem, jakie dokonuje się w najlepszej cząstce narodu wybranego. Bóg z „Reszty” tworzy nową wspólnotę, z nią zawrze nowe przymierze. „Reszta” przyjmuje uniwersalne znaczenia, gdyż cechuje ją odejście ze sfery etnicznej, a przejście $\mathrm{w}$ sferę duchową; z przymierza pieczętowanego krwią zwierząt do przymierza we krwi Syna Bożego.

„Oto Ja dokonuję rzeczy nowej” (Iz 43,19). Wyodrębniają się dwie linie profetyczne; jedna kieruje do oczekiwania Mesjasza, druga do głoszenia nowego Ducha, a zbiegają się one w niewielkiej Reszcie, w ludzie „ubogich” (anawim Jahwe), oczekujących „pociechy Izraela” i „wyzwolenia Jerozolimy”.

Stąd „Reszty” nie stanowi grupa narodowo czystych Żydów, lecz wspólnota wiary. Mamy do czynienia z przejściem z kwalifikacji ilościowej na jakościową.

Por. A. Napiórkowski, Od Arki Przymierza Jahwe do Kościoła Trójjedynego Boga, Pelplin 2019, s. 54-56. 
„Reszta” oznacza tych, co mają „nowe serce i ducha nowego”. A ponieważ są nimi ci, co uwierzą w Chrystusa, to wolno mówić o uniwersalizmie Zbawienia. Ta powszechność Odkupienia oznacza tak pełnię łaski, jak i jej dostępność dla wszystkich, zarówno Żydów, jak i pogan ${ }^{5}$.

W drugim etapie powstawania Kościoła znajdujemy kobiety, które są typem Maryi. Niewiastą opiewaną w Starym Testamencie, która dzięki wierności i prawu Bożemu broni swoją ojczyznę jest Judyta. Judyta to bez wątpienia zapowiedź Maryi. Obok odważnej Judyty („Judyt wojująca”), prefigurą Maryi jest Rut. Mimo że nie jest ona Izraelitką, to kocha swoja teściową Noemi i jej naród izraelski. Rut opuszcza swoją ojczyznę, idzie do Judei i Betlejem, poślubia Hebrajczyka i zostaje włączona w genealogię króla Dawida i przyszłego Mesjasza Jezusa, który narodzi się z Maryi. Rut uosabia wielkoduszne zawierzenie Bogu i pójście za Jego głosem, to, co w całej pełni zrealizuje w sobie Maryja. Na kartach Starego Testamentu odnajdujemy także Esterę, która jako Żydówka mieszka pośród wrogów (Asyryjczyków). Dzięki jej poświęceniu i wstawiennictwu, zostaje uratowana cząstka narodu wybranego. Estera to obraz Maryi, chroniącej wspólnotę wierzących w Chrystusa poprzez swoje wstawiennictwo u swojego Syna.

Oprócz tych kobiet, które egzegeza w sposób typiczny odnosi bezpośrednio do Maryi, można przywołać wiele innych kobiet, jakie pełnią szczególne funkcje w Starym Testamencie. Na pewno były ważne matki, które przekazywały życie oraz żony patriarchów (Sara, Rebeka, Lea), położne, Miriam - siostra Mojżesza, Rachab, Aksa - córka Kaleba, matka Samsona, Anna - matka Samuela ${ }^{6}$.

Analizując eklezjogenezę starotestamentalną, odkrywamy też kobiety (Ewa, Debora, Judyta, Rut, Estera), które są prefigurą Maryi. Pismo Święte Starego Testamentu ukazując typiczne początki Kościoła, daje podstawę do pozytywnego stwierdzenia, iż zasada Piotrowo-Maryjna pojawia się już na dwóch pierwszych etapach kościelnej społeczności, czyli w pozaczasowej idei Boga Ojca oraz konstytuowaniu się jego w Starym Przymierzu z Abrahamem i Mojżeszem?

Przejdźmy teraz do trzeciego etapu procesu powstawania Kościoła, a mianowicie do jego ustanowienia przez Jezusa. Do nowotestamentalnych aktów eklezjotwórczych zaliczamy następujące wydarzenia: wezwanie uczniów i uczennic do naśladowania, ustanowienie Kolegium Dwunastu Apostołów, przyznanie statusu prymacjalnego Szymonowi Piotrowi, sprawowanie Ostatniej Wieczerzy

Por. tamże, s. 47-50.

6 Por. T. M. Dąbek, „Nie ma już mężczyzny ani kobiety, wszyscy bowiem jesteście jednym w Chrystusie Jezusie" (Ga 3,28). Biblia o godności ipowołaniu kobiety, Kraków 2012, s. 49-59.

7 Por. A. Napiórkowski, Proegzystencja Kościoła, s. 71-75. 
jako podarowanie siebie, krzyż jako objawienie solidarności z wszystkimi cierpiącymi, męka i śmierć oddaniem życia dla wspólnoty „za nasze grzechy”, ukrzyżowanie jako doskonałe posłuszeństwo Ojcu Niebieskiemu i miłość bez granic wobec grzeszników oraz Zmartwychwstanie. W tych słowach, gestach i swej osobie Jezus tworzy z Izraela i pogan nową, Bosko-ludzką wspólnotę. Jego Kościół nie jest jednak celem samym w sobie, ale przyporządkowany Królestwu Bożemu jest znakiem i narzędziem pojednania człowieka i świata z Trójcą Świętą.

W aktach eklezjotwórczych Jezusa odnajdujemy wielokrotnie Maryję, Jego matkę. W porządku chronologicznym Maryja uprzedza nie tylko Kościól, ale nawet jego fundatora, historycznego Jezusa z Nazaretu ${ }^{8}$. Trzeba tu dostrzec obecność i rolę Maryi w takich wydarzeniach, jak Wcielenie, działalność nauczycielska i cudotwórcza Jezusa oraz wydarzenia paschalne (Jego Męka, Śmierć i Zmartwychwstanie). Zrodzenie Jezusa jako głowy Kościoła poprzedza scena Zwiastowania (por. Łk 1, 26-38), gdzie nie bez znaczenia jest zgoda „Amen” na Boży plan Zbawienia, który przecież realizuje się w sposób sakramentalny przez Kościól. Aktywna rola Maryi ujawnia się w czasie godów w Kanie Galilejskiej, na podstawie której mówimy o Jej pośrednictwie w Kościele. U synoptyków znajdujemy scenę, ukazującą Świętą Dziewicę jako prawdziwego słuchacza słowa Bożego (por. Mt 12, 46-50; Mk 4, 21-25; Łk 8, 19-21). Jezus uczy: „moją matką i moimi braćmi są ci, którzy słuchają słowa Bożego i wypełniają je" (Łk 8, 21). Słuchając słowa Bożego, Maryja rozważa je w sercu, kontempluje, modli się, wnika w treść Objawienia i tym samym współuczestniczy w powstawaniu Kościoła. W tym kontekście zasada Maryjna oznacza posłuszeństwo wobec Jahwe, akceptacje i przyjęcie słowa, modlitwę i kontemplację.

Jednym z aktów eklezjotwórczych Jezusa jest tajemnica Jego krzyża. Maryja jest świadkiem narodzin Kościoła pod krzyżem. Mocą duchowego testamentu Jezusa, została uczyniona matką Kościoła. „Kiedy więc Jezus ujrzał matkę i stojącego obok Niej ucznia, którego miłował, rzekł do niewiasty: «Niewiasto, oto syn Twój». Następnie rzekł do ucznia: «Oto Matka twoja». I od tej godziny uczeń wziął ja do siebie" (J 19, 26-27). Z tych słów Jezusa wynika podwójne zobowiązanie, które odnosi się tak do Maryi, jak i do wszystkich naśladowców Jezusa. Maryja ma zlecone przez swojego Syna, aby była matką Jego Kościoła. Nam zaś jest nakazane, abyśmy Ją przyjęli za matkę. Z kolei myśl patrystyczna upatrując narodzin Kościoła w momencie wypłynięcia krwi i wody z przebitego boku Chrystusa, podkreślała historyczną obecność Maryi w tym powstawaniu sakramentu Kościoła. Święty Ambroży wyznaje: „Jak Ewa została utworzona

Por. M. Rosik, Obecność Maryi w narodzinach Kościoła w świetle Nowego Testamentu, „Salvatoris Mater” 2007, 9/3/4, s. 11-28. 
z boku śpiącego Adama, tak Kościół narodził się z przebitego serca Chrystusa, który umarł na krzyżu"'.

Niemiecki biblista, J. Gnilka, akcentuje narodziny Kościoła w Wieczerniku i łączy je z obecnością Maryi. Łukasz w Dziejach Apostolskich wzmiankuje to lapidarnie: „wszyscy oni trwali jednomyślnie na modlitwie, razem z niewiastami, Maryją, Matką Jezusa i braćmi Jego" (Dz 1, 14). Wydaje się, że rola Maryi w tworzeniu się Jezusowej wspólnoty tak w okresie przedpaschalnym jak i popaschalnym jest niezbywalna ${ }^{10}$.

Czwarty etap w procesie powstawania Kościoła rozpoczyna się w momencie Pięćdziesiątnicy. Zesłanie Ducha Świętego dopełnia paschalną tajemnicę Chrystusa i rozpoczyna aktywną działalność Kościoła, obejmującą swoim zasięgiem wszystkie ludy i cały świat stworzony (por. Dz 4, 42-44). Działanie Ducha jest zarówno zewnętrzne (zbawcza wspólnota instytucjonalna), jak i wewnętrzne (osobowe, duchowe). Duch Jezusa sprawia, że wysłużone przez Niego dobra zbawcze mogą być udzielane wierzącym sakramentalnie, a także w pewien sposób całemu światu. Jak Maryja była obecna przy narodzeniu Jezusa, tak jest również w momencie narodzin Kościoła, mistycznego ciała Chrystusa, który rozpoczyna swoją misję. „Wszyscy oni trwali jednomyślnie na modlitwie, razem z Maryją" (Dz 1, 14). Zasada Maryjna na czwartym etapie realizowania się Kościoła, który wiąże się z Pięćdziesiątnicą, wypowiada się w charakterze służebnym. Maryja wraz z uczniami Jezusa prosi Boga Ojca o dar Ducha ${ }^{11}$.

Jedność Maryi z Duchem Świętym w świetle eklezjogenezy nowotestamentalnej jest jednak znacznie bogatsza niż tylko aspekt służebny, gdyż posiada ona wiele form i sposobów. Trzeba by też rozważyć szerzej tajemnicę Niepokalanego Poczęcia. Mariolodzy wyróżniają cztery zasadnicze modele zjednoczenia Matki Jezusa z trzecią osobą Boską: 1. Synergia w działaniu między Duchem Świętym a Maryją; 2. Maryja jako przybytek Ducha Świętego (namiot spotkania, arka przymierza, świątynia, sanktuarium); 3. Maryja obrazem i ikoną Ducha; 4. Maryja objawieniem i przejrzystością (transparencją) Ducha Świętego ${ }^{12}$.

Uprzedzającym obrazem dla Pięćdziesiątnicy, czyli Zstąpienia Ducha Świętego na Kościół jest przeniknięcie Maryi Duchem Świętym. Spiritus Creator wzbudza w Niej nowe życie, i dzięki temu staje się matką Mesjasza. Oprócz

9 Ambroży z Mediolanu, Expositio Evangelii secundum Lucam, 2, 85-89, [w:] Patrologia Latina 15, 1583-1586.

10 Por. M. Rosik, Obecność Maryi w narodzinach Kościoła w świetle Nowego Testamentu, s. $17-21$.

11 Por. A. Napiórkowski, Proegzystencja Kościoła, s. 81-88.

12 Por. tenże, Maryja jest piękna. Zarys mariologii i maryjności, Kraków 2016, s. 150-152. 
poczęcia i zrodzenia Syna Bożego, Maryja - podobnie jak Kościół - zostaje wyposażona w dary Ducha Świętego. Jest pierwszą charyzmatyczką.

Przejdźmy teraz do ostatniego etapu dynamicznego powstawania Kościoła, jaki wypowiada się w Jego zdążaniu ku eschatologicznej pełni. Pielgrzymujący Kościół nie jest bowiem ostatecznym celem i spełnieniem odwiecznego zamysłu Trójjedynego Boga, aby pojednać ze sobą człowieka i całe stworzenie. Poprawne rozumienie Kościoła jest uchwycone w sposób odpowiedzialny, gdy jego powstanie, naturę i misję scalamy z eschatologią, czyli rzeczami ostatecznymi. W tę perspektywę eschatyczną wpisuje się Niewiasta, rodząca Kościól w świetle Apokalipsy, por. Ap 12, 1-18. Podstawowe znaczenie apokaliptycznej wizji powiązane jest z prześladowaną wspólnotą, ale także z ukazaną w tym fragmencie Niewiastą, posiadającą rysy Matki Mesjasza (por. Iz 7,11-14; Mi 5,2). Motyw ucieczki Niewiasty na pustynię odnosi się do Niewiasty, symbolizującej pielgrzymujący Kościół, który wciąż zmaga się ze złem. Prześladowanie i ocalenie Niewiasty to profetyczna figura cierpienia Kościoła i jego ostatecznego zwycięstwa. Tekst dwunastego rozdziału Apokalipsy łączy w sobie eklezjologię i mariologię ${ }^{13}$.

Jakkolwiek wymieniliśmy pięć etapów tworzenia się Kościoła, to musimy pamiętać, iż Kościół ciągle staje się na nowo dzięki Duchowi Świętemu w zbawczym udzielaniu się Zmartwychwstałego Pana i przyjmującego Go grzesznika. Ponadto ów piąty - eschatologiczny - etap nie jest przecież zakończony, dlatego Wniebowzięta Maryja jako Matka Kościoła i Oblubienica Ducha Świętego nieustannie musi orędować za swoimi pielgrzymującymi braćmi i siostrami. Oznacza to, iż urzędowe podmioty kościelnej struktury winny bez przerwy krytycznie się rewidować w świetle zasady Maryjnej.

\section{Rozwój rozumienia Kościoła w ciąu jego dziejów i maryjne implikacje}

$\mathrm{Z}$ analiz biblijnych możemy wyprowadzić następujące kategorie Kościoła, jakie funkcjonują w dzisiejszej eklezjologii, a mianowicie: Lud Boży, Mistyczne Ciało Chrystusa, Świątynia Ducha Świętego, Dom Boży, wspólnota (communio / koinonia) oraz powszechny Sakrament Zbawienia. W historii Kościoła jedna z kategorii stawała się często naczelną, a pozostałe traktowano podrzędnie. Odwołując się do zasady kongruencyjnej, trzeba pamiętać, iz Kościół Trójjedynego Boga jest rzeczywistością zbyt złożoną, aby mógł się wyczerpać tylko w jednej z powyższych kategorii. Lud Boży, Mistyczne Ciało Chrystusa,

13 M. Rosik, Obecność Maryi w narodzinach Kościoła w świetle Nowego Testamentu, s. 23-26; A. Napiórkowski, Proegzystencja Kościoła, s. 88-89. 
Świątynia Ducha Świętego, Dom Boży, wspólnota i sakrament wzajemnie się uzupełniają, a nie znoszą.

Przyjrzyjmy się teraz pokrótce ujęciom chrześcijańskiej wspólnoty w ciągu jej historyczno-dogmatycznego rozwoju. W pierwszych pięciu stuleciach Kościół to charyzmatyczna struktura, która swoją kościelną świadomość zyskuje na liturgii, w przepowiadaniu oraz $\mathrm{w}$ trakcie intelektualnych sporów, jakie toczone są ze środowiskiem judaistycznym, ze światem pogańskim oraz wewnątrz samego Kościoła, który poszukuje odpowiedzi na wiele pytań, wiążących się $z$ interpretacją Objawienia i artykulacją jego wiary. Prześladowania powodują paradoksalnie wzrost liczby wyznawców, a z krwi męczenników rodzą się nowi wierzący. Chrześcijański monoteizm zderza się z politeizmem ówczesnego świata i synkretyzmem religijnych kultów. Zajmują się tym nie tylko pojedynczy pisarze poapostolscy czy Ojcowie Kościoła, ale prawdy wiary są dogmatycznie formułowane na synodach oraz soborach. Istotną przestrzenią realizowania naśladowania Jezusa jest ogromny ruch monastyczny, przyjmujący formy cenobityczne i eremickie.

W ciągu następnych pięciu wieków można opisać Kościól jako cesarstwo Boże, co jest konsekwencją darowizny Pepina Małego oraz utworzenia Państwa Kościelnego (Patrimonium Sancti Petri) w 755 roku, przy wsparciu Karola Wielkiego. Papieże stają się świeckimi monarchami. Jakkolwiek cześć do Najświętszej Marii Panny nie ustaje, to jednak Jej pozycja w Kościele instytucjonalnym ulega pomniejszeniu. W VI wieku pojawiła się idea służebnego oddania się Maryi, np. u Ildefonsa z Toledo.

Kościół średniowieczny w XI i XII wieku charakteryzuje „rewolucja gregoriańska”. Podjęto walkę z symonią, z zepsuciem moralnym kleru, zajęto się czystością doktryny. Papież Grzegorz VII (1073-1085) rozpoczął działania o osiągnięcie niezależności Kościoła od możnych suwerenów. W ówczesnym porządku feudalnym chodziło o uwolnienie Kościoła spod władzy świeckiej z jednej strony, a z drugiej, o centralizację Kościoła pod absolutną władzą Papieża przez wzmocnienie karności kościelnej. Walka o tzw. inwestyturę naznaczyła wiek XI, prowadząc ostatecznie do jeszcze większej instytucjonalizacji i zaakcentowania widzialnego wymiaru Kościoła. To z kolei w XII i XII stuleciu wzmogło potrzebę reform i dowartościowania wymiaru duchowego. W ten nurt trzeba wpisać powstawanie uniwersytetów, rozwój myśli filozoficznej (Hugona od św. Wiktora, Anzelma z Canterbury, Piotra Abelarda, Piotra Lombarda, Henryka z Gandawy, Roberta Grosseteste) oraz rozwój teologii (Bonawentura, Albert Wielki, Tomasz z Akwinu, Roger Bacon, Jan Duns Szkot). Krytyczna myśl uniwersytecka prowadziła do napięcia między Kościołem hierarchicznym a charyzmatycznym. Nowo powstałe zakony żebracze rozpowszechniały ponadto wizję Kościoła jako Mistycznego Ciała Chrystusa. W reformę Kościoła 
tego okresu swój wkład wnieśli zakonnicy z opactwa Cluny, w co także można włączyć Bernarda z Clairvaux, który zapoczątkował mariologię jako odrębną jednostkę w teologii z jej ukierunkowaniem na chrystologię ${ }^{14}$.

W nurcie maryjnej pobożności ludowej oraz duchowości zakonów średniowiecznych Maryja wyraźnie jest obecna, rozwija się maryjne pośrednictwo lask oraz modlitwa wstawiennicza do Niej, o czym świadczą liczne średniowieczne spisy cudów. W pobożności średniowiecznej Najświętsza Panna przedstawiana jest przyodziana w płaszcz, pod którym chronią się Jej czciciele, zwłaszcza zakonnicy i świeccy fundatorzy ${ }^{15}$. Równolegle z podziałem na Kościół hierarchów oraz Kościól zakonników i świeckich, pojawia się w nauce o Maryi rozdział na mariologię oficjalną, praktykowaną przez elity oraz maryjność ludową, nasilającą się w praktykach ludowych, aż po wezwania Maryi, aby odpuściła grzechy i zbawiła. Dochodzi nawet do przeciwstawiania miłosierdzia Maryi sprawiedliwości Bożej.

Mimo kolejnych prób reform w Kościele w XIV i XV wieku, hierarchia nie zdobywa się na wysiłek radykalnych zmian. Więcej nawet, mamy do czynienia w XVI stuleciu z apogeum władzy, polityki i gospodarczej potęgi Państwa Kościelnego. Zewnętrznym przejawem głębokiego kryzysu jest „niewola awiniońska" (1378-1417), dzieląca Kościół na papistów i koncyliarystów. Kres tej schizmie kładą obrady Soboru w Konstancji (1414-1418) oraz elekcja papieża Marcina V. Z kolei Sobór w Bazylei (1431-1439) uchwalił dekrety, których celem było zwiększenie dyscypliny wśród kleru. Obradujący w latach 1439. 1445, Sobór Florencki doprowadził do czasowej unii z Kościołem greckim.

Rozumienie Kościoła jako świeckiego państwa Bożego znalazło swoje potwierdzenie w inicjowaniu wypraw krzyżowych. Niezgoda na ujęcie Kościoła jako feudalnego imperium ujawniła się w poszukiwaniu przez świeckich nowych i różnych form duchowości (katarzy, albigensi, husyci, waldensi), w tym także maryjnej ${ }^{16}$.

Zdecydowana negacja takiego nadmiernie świeckiego, instytucjonalnego Kościoła wypłynęła z postulatów reformacyjnych w XVI wieku, w których żądano przejścia do niewidzialnej wspólnoty świętych. Wezwanie do rewizji dotychczasowej kościelnej i hierarchicznej tradycji w świetle słowa Bożego i zasady usprawiedliwienia, stworzyło też inną mariologię i maryjność. Ewangelicy odmówili Maryi aktywnej roli w dziele Odkupienia, zaznaczając, że Ona

14 Por. J. Ratzinger/BenedyktXVI, H.U. von Balthasar, Maryja w tajemnicy Kościoła, Kraków 2007, s. 23.

15 Por. S. C. Napiórkowski, Maryja. W Duchowości, [w:] Encyklopedia Katolicka, t. XII, Lublin 2008, k. 27-29.

16 Por. A. Napiórkowski, Bosko-ludzka wspólnota. Podstawy katolickiej eklezjologii integralnej, Kraków 2010, s. 175-185. 
go sama potrzebowała, dlatego nie może być pośredniczką Chrystusa. Marcin Luter odrzucił wstawiennictwo Maryi, dopuszczając Jej modlitwę za nas. Z kolei Jan Kalwin zanegował naukę o Jej dziewictwie, znosząc w Genewie nawet wszystkie święta maryjne ${ }^{17}$.

Sprzeciw wobec nadużyć moralnych, dyscyplinarnych wraz z zakwestionowaniem nadmiernie rozbudowanych wymiarów widzialnych przez potężne ruchy reformacyjne w łonie chrześcijaństwa, doprowadził do zwołania Soboru Trydenckiego (1545-1563), który paradoksalnie jeszcze bardziej dowartościował rozumienie Kościoła jako societas perfecta. Podobne przesunięcia dokonały się w mariologii i maryjności. Protestancka ortodoksja nadmiernie powściągliwa w stosunku do Najświętszej Panny, wywołała katolicką przesadę w obszarze pobożnościowym ${ }^{18}$. Wątła mariologia uaktywniała instytucjonalną eklezjologię.

Kolejny etap zmian w nauce o Kościele wiąże się z okresem deizmu i oświeceniowego absolutyzmu. W wieku XVII i XVIII sytuacja Kościoła ulega dość istotnym zmianom, gdyż władcy absolutni dążą do podporządkowania sobie Kościoła i uniezależniania Go w swoich krajach od związków z Biskupem Rzymu (józefinizm, anglikanizm, febronianizm). Uszczerbku doznaje na tym również zasada kolegialności, gdyż zostaje naruszone znamię powszechności Kościoła i relacje biskupów między sobą i Papieżem.

Istotne zmiany tak w eklezjologii jak i mariologii przynosi wiek XIX. Dzięki pracy szkół teologicznych w Tybindze i Rzymie dokonuje się jednak powolne odchodzenie od eklezjologii instytucjonalnej i wypracowanie integralnego obrazu Kościoła w jego widzialności i pneumatyczności. A w obszarze mariologii nie wolno pominąć dokonań M.J. Scheebena, który ją zintegrował z teologią dogmatyczną i rozwinął ideę macierzyństwa oblubieńczego, gdzie Maryja związana z Chrystusem jest ideałem dla Kościoła i duchową matką ludzi ${ }^{19}$.

Ta szkicowa prezentacja historii rozwoju myśli o Kościele musi naturalnie przywołać wydarzenie i postanowienia Soboru Watykańskiego II (1962-1965), który w zakresie eklezjologii okazał się nie tylko kontynuacją Soboru Watykańskiego I (1869-1870), ale zdecydowanym odejściem od eklezjologii jurydycznej i wypracowaniem rozumienia Kościoła jako komunii sakramentalnej. A mariologia została włączona w treść konstytucji dogmatycznej o Kościele Lumen gentium, tworząc ósmy rozdział tego dokumentu Błogosławiona Maryja dziewica, Boża rodzicielka, w misterium Chrystusa i Kościoła. Odejście od zniekształconej mariologii tytułów oraz przywilejów i przejście do mariologii

17 Por. S. C. Napiórkowski, Maryja. W duchowości, k. 24-25.

18 A. Napiórkowski, Bosko-ludzka wspólnota, s. 185-192.

19 S. C. Napiórkowski, Maryja. W duchowości, k. 29-30. 
dynamicznej dziejów Zbawienia, pozwoliło nie tylko wprowadzić Maryję do grona pielgrzymującego Ludu Bożego, ale oczyściło zasadę Piotrową 20

$\mathrm{Z}$ powyższego widać, że mariologia $\mathrm{w}$ ramach uprawianej wcześniej przez wiele wieków eklezjologii instytucjonalnej, była zdegradowana do emocjonalności i uczuciowości. Prowadziło to w skrajnych przypadkach nawet do takiego stopnia oderwania Bożej Rodzicielki od całości Objawienia, że Jej walory i możliwości przeciwstawiono Chrystusowi czy też niekiedy wywyższano Ją ponad Boga Ojca lub ponad Ducha Świętego. Z kolei w reformatorskiej eklezjologii, gdzie Kościól pozbawiono instytucji i sakramentalności, nauka o Maryi doznała autentycznego zubożenia, posuniętego do zaprzeczania czasem podstawowych dogmatów maryjnych i prawdy o Jej pośrednictwie. Nie można zatem konstruować odpowiedzialnej eklezjologii bez głębokiego łączenia jej z pneumatologii i mariologią.

\section{W kierunku niezbywalnej kolegialności}

Już Paweł Apostoł uczył, iż jakkolwiek nie wszyscy w Kościele powołani są do świętości, to jednak nie wszyscy mają do spełnienia tę samą misję. W jego listach do Koryntian, Galatów czy Efezjan czytamy, iż nie każdy jest Apostołem, prorokiem, nauczycielem, Ewangelistą czy pasterzem (por. 1 Kor 12, 28; Ga 6, 6; Ef 4, 11). A ponieważ Kościół - jak to już wykazaliśmy powyżej, prezentując eklezjogenezę biblijną oraz rozwój jego rozumienia w dziejach - nie jest systemem doktrynalnym czy też ludzką społecznością, ale jest nadprzyrodzoną wspólnotą, w której Bóg udziela swoich darów zbawczych przez odpowiednio do tego powołane osoby. Ludzie ci, ponieważ chodzi tu o Zbawienie, muszą mieć urząd sakramentalny, służący tak jedności w prawdach wiary, jak i dla udzielania sakramentów oraz zapewniający historyczną ciągłość z Kościołem Apostołów, których następcami są biskupi. Ten sakramentalny urząd, w swoich trzech stopniach: biskupa, prezbitera i diakona, sprawia duchowe skutki, jakie Duch Święty rozprowadza w Mistycznym Ciele Chrystusa, którym jest Kościół121.

W hierarchicznej strukturze Kościoła, posiadającej sakramentalną naturę, szczególne miejsce przysługuje biskupom, którzy w łączności z wszystkimi innymi biskupami na świecie oraz z Biskupem Rzymu, tworzą Kolegium Biskupów Kościoła powszechnego. To Kolegium, zwane inaczej Episkopatem, uczy, uświęca i zarządza Chrystusową owczarnią ${ }^{22}$. Kolegialne Magisterium Biskupów i Papieża swoją posługę spełnia w trzech formach: 1. Na soborze powszechnym,

\footnotetext{
20 A. Napiórkowski, Bosko-ludzka wspólnota, s. 197-204.

21 Por. G. L. Müller, Dogmatyka katolicka, Kraków 2015, s. 631-634.

22 Por. KK 19.
} 
jako Kolegium wspólnie z Papieżem (por. KK 22); 2. Na synodach prowincjalnych albo konferencjach Episkopatu, kiedy dochodzi do kolegialnego działania Papieża z biskupami (por. KK 22); 3. Papież samodzielnie (ex esse) jako Następca św. Piotra, działając jako głowa Kolegium Biskupów (por. KK 22; 25) ${ }^{23}$.

W obliczu poważnych dramatów, jakie dzisiaj znaczą ludzkość tak w skali lokalnej, jak i globalnej, Kościół Boży winien na nowo człowiekowi przekazywać orędzie nadziei. Wojny domowe, terroryzm, bieda i rozbój, nędza uchodźców, nasilające się uzależnienie od narkotyków i pornografii, wzrastające wskaźniki samobójstw, kryzys sensu i duchowo-moralna dezorientacja milionów - to wyzwania, które zmuszają Kościół do bycia światłem w tych ciemnościach. Trzeba jednak pamiętać, iż Kościół nie jest światłem, lecz ma dać świadectwo o tym świetle, którym jest Jezus Chrystus, Syn Boży i Odkupiciel wszystkich ludzi. Dlatego podejmowanie w tym kontekście problematyki kolegialności nie może być spekulatywną dyskusją, aby wzmacniać kościelną instytucjonalność, ale winno prowadzić do usprawnienia jego służby. Kościól, który zajmowałby się dziś jedynie tylko własnymi strukturalnymi problemami, byłby dość anachroniczny i obcy światu. Nie wolno tracić z oczu prawdy, iż w swoim istnieniu i w swoim posłannictwie nie jest on niczym innym, jak Kościołem Trójjedynego Boga, źródła i celu każdego człowieka i całego kosmosu ${ }^{24}$.

Stąd refleksja nad sposobem wykonywania najwyższej władzy w Kościele - którą sprawują Papież jako Biskup Rzymu oraz wszyscy biskupi świata cum et sub Petro - nie może pozbywać się swego fundamentalnego odniesienia, jakim jest ludzkie pytanie o Boga. Nie ma tu potrzeby przytaczania soborowej nauki o jedności prymatu i Episkopatu w całej jej rozciągłości ${ }^{25}$, ale warto podkreślić, że tak Papież, jak i biskupi wskazują w swoim posługiwaniu na Chrystusa, Który jedynie w Duchu Świętym może udzielić człowiekowi i światu nadziei. Przesadna centralizacja zarządzania Kościołem nie będzie pomocna,

23 Por. G. L. Müller, Dogmatyka katolicka, s. 640.

24 Por. Tenże, Kollegialität und Ausübung der höchsten kirchlichen Vollmacht. Anmerkungen zum Apostolischen Schrieben Evangeliigaudium, „Osservatore Romano” (deutsche Ausgabe), 30. Januar 2014, s. 4-5.

25 KK 22: „Kolegium albo ciało biskupie posiada władzę autorytatywną jedynie wtedy, gdy się je bierze łącznie z Biskupem Rzymskim, następcą Piotra, jako jego głową, i gdy nienaruszoną zostaje władza zwierzchnia tego ostatniego nad wszystkimi, zarówno Pasterzami, jak wiernymi. Albowiem Biskup Rzymski z racji swego urzędu, mianowicie urzędu Zastępcy Chrystusa i Pasterza całego Kościoła, ma pełną, najwyższą i powszechną władzę nad Kościołem i władzę tę zawsze ma prawo wykonywać w sposób nieskrępowany. Stan zaś biskupi, który jest następcą Kolegium Apostolskiego w nauczycielstwie i w rządzeniu pasterskim, co więcej, w którym trwa nieprzerwanie ciało apostolskie, stanowi również razem z głową swoją, Biskupem Rzymskim, a nigdy bez niego, podmiot najwyższej i pełnej władzy nad całym Kościołem, władza ta jednak może być wykonywana nie inaczej jak tylko za zgodą Biskupa Rzymskiego". 
lecz znacznie utrudni jego misjonarską działalność. Kolegialność bowiem w swym podstawowym założeniu ma wzmocnić dynamikę misyjności Kościoła, a szczególnie w zadaniach nowej ewangelizacji, która była przedmiotem obrad Synodu Biskupów w 2012 roku. Dotykamy tu poważnego zagadnienia, jakim jest ewangelizacja. Warto pamiętać o uprzednich znakomitych dokumentach w tej kwestii, a mianowicie: Evangelii nuntiandi Pawła VI z 1975 roku oraz będącego dziełem V Konferencji Ogólnej Episkopatów Ameryki Łacińskiej i Karaibów, obradującej w Aparecida w Brazylii w 2007 roku. Sam Franciszek wyzna - udzielając wywiadu hiszpańskiej gazecie „El Pais” w styczniu 2017 roku - że pastoralne ramy jego posługi zawarte są w Evangelii nuntiandi oraz dokumencie z Aparecida. Opierając się na tych dwóch pismach, przedłożył w 2013 roku Adhortację Evangelii gaudium, wykreślającą podstawy jego rozumienia Kościoła i zasady kolegialności ${ }^{26}$.

W orędziu XIII Zwyczajnego Zgromadzenia Ogólnego Synodu Biskupów, które rozpoczęło się w 2011 roku i podjęło temat nowej ewangelizacji dla przekazu wiary chrześcijańskiej, czytamy:

Prowadzenie ludzi naszych czasów do Jezusa, na spotkanie z Nim, jest sprawą niecierpiącą zwłoki we wszystkich regionach świata, tych, w których ewangelizacja nastąpiła dawno bądź ostatnio. Wszędzie bowiem odczuwa się potrzebę ożywienia wiary, której grozi osłabienie w kontekstach kulturowych, które uniemożliwiają jej zakorzenienie się w życiu osobistym ludzi i obecność w społeczeństwie, jasne przekazywanie treści i wynikające stąd owoce (...). Zmienione okoliczności społeczne, kulturalne, ekonomiczne, polityczne i religijne wymagają od nas czegoś nowego: abyśmy przeżywali w nowy sposób nasze wspólnotowe doświadczenie wiary i ją głosili, poprzez ewangelizację „nową w swym zapale, w swych metodach, w swym wyrazie" (przemówienie do uczestników XIX Zgromadzenia CELAM, Port-au-Prince, 9 marca 1983 roku, n. 3), jak powiedział Jan Paweł II, ewangelizację, którą - przypomniał Benedykt XVI - adresowana jest „zasadniczo do osób, które chociaż zostały ochrzczone, oddaliły się od Kościoła i żyją bez odnoszenia się do praktyki chrześcijańskiej (...), aby sprzyjać w przypadku tych osób nowemu spotkaniu z $\mathrm{Pa}$ nem, bo tylko On napełnia nasze ludzkie życie głębokim sensem i pokojem; aby sprzyjać odkryciu na nowo wiary, źródła łaski, niosącej radość i nadzieję w życie osobiste, rodzinne i społeczne"27.

Dlatego w posynodalnej Adhortacji Evangelii gaudium Franciszek wezwał papiestwo oraz centralne struktury Kościoła powszechnego do wsłuchania się w wezwanie do nawrócenia. Pisał tam:

26 Por. S. Scheingraber, Aufbruch zur „verbeulten Kirche“. Die Ekklesiologie von Papst Franziskus, Echter Würzburg 2019, s. 27-43.

27 Orędzie XIII Zwyczajnego Zgromadzenia Ogólnego Synodu Biskupów do Ludu Bożego, Rzym $26 \mathrm{~V} \mathrm{2012,} \mathrm{nr} 2$. 
Sobór Watykański II stwierdził, że w sposób analogiczny do Kościołów patriarchalnych, Konferencje Episkopatów mogą „dziś wnieść wieloraki i owocny wkład do konkretnego urzeczywistnienia się poczucia kolegialności”. Jednak to życzenie nie urzeczywistniło się w pełni, ponieważ nie przyją jeszcze wystarczająco wyraźnego kształtu statut Konferencji Episkopatów, który by pojmował je jako podmioty o konkretnych kompetencjach, łącznie z pewnym autentycznym autorytetem doktrynalnym. Nadmierna centralizacja zamiast pomagać, komplikuje życie Kościoła oraz jego dynamizm misyjny ${ }^{28}$.

Przykładem łączenia kolegialności i maryjności są dla Papieża chrześcijanie Wschodu, stąd w Evangelii gaudium odwołuje się do nich: „w dialogu z braćmi prawosławnymi my, katolicy, mamy możliwość nauczenia się czegoś więcej na temat znaczenia kolegialności biskupów oraz o ich doświadczeniu synodalności. Poprzez wymianę darów Duch może nas coraz bardziej prowadzić do prawdy i dobra"29.

Nie naruszając w żaden sposób sakramentalnego pośrednictwa zbawczego, jakie powiązane jest $z$ urzędem biskupim, pojawiła się papieska sugestia większego dowartościowania kompetencji Episkopatów, aby wyjść naprzeciw nowym wyzwaniom misyjnym Kościoła.

Trzeba jednak pamiętać, że nadmierne dowartościowanie Kościołów lokalnych nie tyle będzie osłabieniem papieskiego centralizmu, co będzie prowadzić do zachwiania powszechności Kościoła katolickiego. Niektórzy historycy sądzą, że Ateny wzbudzają zainteresowanie, gdyż importowały pszenicę i eksportowały oliwę. Pojawili się też i teolodzy, którzy twierdzą, iż jednocząca i integrująca funkcja Rzymu dla chrześcijan staje się zbyteczna w pluralistycznym świecie.

Błędne rozumienie tzw. swobodnego wyrażania katolickiej myśli, jakie wprowadził Sobór Watykański II odsłania fakt, iż nietolerancja starego papieskiego Rzymu była imperialnym limes nie tyle dla herezji, co dla nierozwagi i populizmu. Ci, którzy próbują oczyścić chrześcijaństwo z jego tysiącletnich naleciałości, aby przywrócić mu rzekomą „pierwotną czystość’, są iluzjonistami. Ogłaszają bowiem „oryginalnymi” i „autentycznymi” wyłącznie te aspekty chrześcijaństwa, które akceptuje pospolita umysłowość ich czasów. Chciałoby się sarkastycznie spuentować, iż od dwóch tysiącleci „pierwotne chrześcijaństwo" przystosowuje się w każdym nowym dziesięcioleciu do panujących poglądów.

28 EG nr 32.

29 EG nr 246. 


\section{Zasada Maryjna i konsekwencje jej zastosowania w eklezjologii}

Z powyższej rekonstrukcji eklezjogenezy starotestamentalnej i nowotestamentalnej oraz różnych ujęć Kościoła przez XX wieków jego istnienia, wyłania się w katolickiej nauce o Kościele rzeczywistość Bosko-ludzka, którą cechuje zarówno tak niezbywalny wymiar niewidzialny, jak i absolutnie konieczny wymiar widzialny. Kościół zatem potrzebuje swojej instytucjonalnej struktury, która jest trachentem Bożej łaski30.

Paschalny Pan po swoim Zmartwychwstaniu gromadzi na nowo uczniów i uczennice w nową wspólnotę Ludzi z Bogiem. Tę wspólnotę wierzących obdarza misją i uzdalnia ją do jej spełnienia. A zatem te oba elementy komunii (communio) i misji (missio) stają się znakiem i narzędziem jedności ludzi z Bogiem i pomiędzy nimi, a swój początek mają w jedności ze Zmartwychwstałym. W tej popaschalnej wspólnocie są obecni tak Maryja jak i Piotr, a zatem spotyka się świętość z instytucją. Według Hansa Ursa von Balthasara zakorzenienie wszystkich urzędów odnosi się do maryjnej świętości Kościoła. Zasadniczą kościelną postawą jest postawa posłusznego zdania się na Jezusa, gdyż tylko On jest pasterzem swojego Kościoła i to On uposaża swoim pełnomocnictwem urząd kościelny. Szwajcarski teolog podkreśla zakotwiczenie wszystkiego, co „urzędowo męskie” w nie do ogarnięcia sferze kobiecości, czyli w posłusznym maryjnym Kościele (Maria Ecclesia).

Relacji między urzędem a świętością Balthasar nie wyraża w przeciwstawianiu Piotra i Maryi. Oznacza to, że w każdym powierzonym urzędzie, który w figurze Piotra otrzymuje obiektywną tylko od Chrystusa pochodzącą łaskę, jaka umożliwia to posłannictwo, znajduje się także odpowiednie naczynie przyjęcia, jakie zakłada subiektywną postawę wiary Świętego Kościoła, co urzeczywistnia się w Maryi. Należy pamiętać, iż „subiektywny Duch” posiadacza urzędu nigdy nie odpowiada „obiektywnemu Duchowi” przyznanego urzędu, czyli przyznanej przez Chrystusa misji i władzy, gdyż posiadacz urzędu kryje w sobie grzeszny brak. Dlatego zawsze w Kościele musi interweniować zasada Maryjna, poprzez którą zostaje zachowana tożsamość „obiektywnego urzędu” i „subiektywnej świętości”. Jednakże przy tym w Maryi, w Świętym Kościele, nie zostaje wyczerpana pełnia obiektywnego Ducha, wiążąca się ze słowem Bożym, urzędem i sakramentem. Maryja stanowi o wiele bardziej dla przyznanego Piotrowi urzędu podstawę do adekwatnej odpowiedzi, na którym powinien ustawić się posiadacz urzędu ze swoją odpowiedzią ${ }^{31}$.

30 Zob. A. Napiórkowski, Reforma i rozwój Kościoła. Duch Boży i instytucja, Kraków 2012, s. 308.

31 Por. M. Kehl, Kirche als Institution. Zur theologischen Begründung des institutionellen Charakters der Kirche in der neueren deutschsprachigen katholischen Ekklesiologie, s. 291-292. 
W dużym stopniu Balthasar przejmuje naukę Augustyna z Hippony o jego prawdziwie miłującym Kościele, o gołębicy (columba) i wspólnocie świętych. Poprzez swoją zasadniczą jedność obiektywnie przyznanej łaski i subiektywnie urzeczywistnianej świętości, Kościół jest tym, który działa właściwie, kiedy w swoich urzędach i sakramentach przekazuje miłość Bożą na ludzki sposób. Ten „Kościół miłości” znajduje się zawsze w jedności z Chrystusem, który działa poprzez swoją miłość i poprzez działanie Kościoła urzędowego, nawet jeśli są to grzeszni posiadacze urzędu. Swoją refleksję na temat uzasadnienia instytucjonalnego charakteru Kościoła teolog z Bazylei rozszerza także o zasadę Janową ${ }^{32}$.

Chrześcijaninem w ogóle może być tylko ten, kto wyraża w całym swoim istnieniu formę posłusznego Chrystusa. Chodzi o to, aby wyrażać sobą jedność wydania się w wierze (kobiecość, „rzeczowo”) z darem Chrystusa (męskość, „formalnie”). Podejmując rozważania na temat chrześcijańskiej postawy i kościelnej instytucji, dość często Balthasar opisuje urzędowe i sakramentalne wymiary w Kościele jako „krystalizację miłości” lub „skrystalizowaną miłość”. Kolejnym aspektem obok miłości, instytucjonalnego urzędu, jest krzyż. Akceptacja krzyża wypływa z przyjęcia postawy posłuszeństwa. Droga ogołocenia (kenozy) winna być tak blisko posiadaczy urzędów, jak bliska jest maryjnej drodze miłości ${ }^{33}$.

Wolno zauważyć, że instytucjonalność urzędu jak i świętość wypływająca $z$ tajemnicy Maryjnej zasady muszą być zintegrowane w Kościele, czyli w całość zbawczego działania Trójcy Świętej. Aby zapobiec przewartościowaniu kościelnych urzędów, trzeba uwzględniać Kościól jako Maryję. Dzięki temu instytucjonalność odkryje prawdę o sobie w posłuszeństwie Maryjnego „amen” i Chrystusowego krzyża ${ }^{34}$.

O pozytywnej funkcji mariologii w eklezjologii pisał także kard. Joseph Ratzinger. Męskiemu, aktywistyczno-socjologicznemu charakterowi Ludu Bożego, przeciwstawiał Kościół (Ecclesia) jako rodzaj żeński. Kościół jest jedynie pełny wówczas, gdy jego struktura i działanie żyją tajemnicą macierzyństwa i miłości oblubieńczej. Ta differentia specifica odróżniała już wyraźnie nowotestamentalny Kościół od pielgrzymującego Ludu Bożego starego przymierza ${ }^{35}$.

Eucharystyczno-chrystologiczne ujęcie Kościoła, jakie dzisiaj funkcjonuje w eklezjologii będzie poprawnie rozumiane tylko wówczas, jeśli będzie zawierać w sobie tajemnicę Maryjną. Najświętsza Panna to słuchająca służebnica zachowana od grzechu przez uprzednią łaskę - wypowiada swoje fiat (amen),

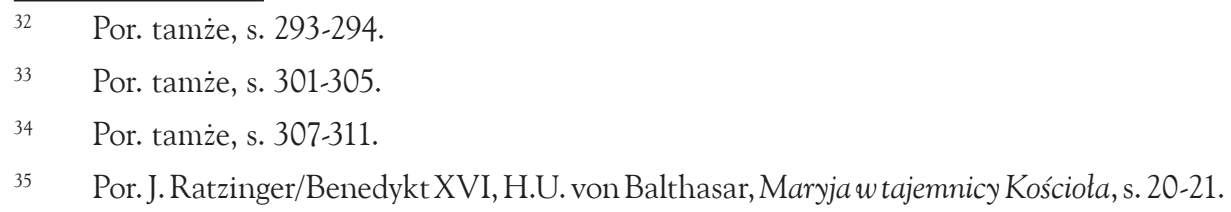


i dzięki temu zostaje wybrana przez Boga Ojca, a w konsekwencji Matką Jezusa, aby stać się także Matką Chrystusowego Kościoła. Urząd Piotra jest tym samym uprzedzony przez miłość i posłuszeństwo Maryi. Warto podkreślić, że Maryja była pierwszą charyzmatyczką, nie posiadając urzędu. Miłość idąca z Bożego Ducha jest bowiem treścią chrystocentrycznego i soteriologicznego spełniania się kościelnego urzędu.

Ukazując Maryję jako Matkę ewangelizacji, Papież wyzna:

Wraz z Duchem Świętym pośród ludu jest zawsze Maryja. Ona gromadziła uczniów, aby Go przyzywać (por. Dz 1, 14), i w ten sposób uczyniła możliwą eksplozję misyjną, jaka się dokonała w dniu Pięćdziesiątnicy. Ona jest Matką ewangelizującego Kościola i bez Niej nie potrafilibyśmy naprawdę zrozumieć ducha nowej ewangelizacji ${ }^{36}$.

Słowa kluczowe: powstawanie Kościoła, eklezjologia, kolegialność, mariologia, ewangelizacja.

\section{Bibliografia:}

1. Ambroży z Mediolanu, Expositio Evangelii secundum Lucam, 2, 85-89, [w:] Patrologia Latina 15, 1583-1586.

2. Dąbek T. M., „Nie ma już mężczyzny ani kobiety, wszyscy bowiem jesteście jednym w Chrystusie Jezusie" (Ga 3,28). Biblia o godności i powotaniu kobiety”, Kraków 2012.

3. Kehl M., Kirche als Institution. Zur theologischen Begründung des institutionellen Charakters der Kirche in der neueren deutschsprachigen katholischen Ekklesiologie, Frankfurt a. M. 1978.

4. Müller G. L., Dogmatyka katolicka, Kraków 2015.

5. Müller G. L., Kollegialität und Ausübung der höchsten kirchlichen Vollmacht. Anmerkungen zum Apostolischen Schrieben Evangelii gaudium, „Osservatore Romano“ (deutsche Ausgabe), 30. Januar 2014, s. 4-5.

6. Napiórkowski A., Bosko-ludzka wspólnota. Podstawy katolickiej eklezjologii integralnej, Kraków 2010, s. 175-185.

7. Napiórkowski A., Maryja jest piękna. Zarys mariologii i maryjności, Kraków 2016.

8. Napiórkowski A., Od Arki Przymierza Jahwe do Kościoła Trójjedynego Boga, Pelplin 2019.

9. Napiórkowski A., Proegzystencja Kościoła, Kraków 2018.

10. Napiórkowski A., Reforma i rozwój Kościoła. Duch Boży i instytucja, Kraków 2012.

11. Napiórkowski S. C., Maryja. W Duchowości, [w:] Encyklopedia Katolicka, t. XII, Lublin 2008, k. 27-29.

12. Orędzie XIII Zwyczajnego Zgromadzenia Ogólnego Synodu Biskupów do Ludu Bożego, Rzym 26 V 2012.

13. Ratzinger J./Benedykt XVI, Balthasar H. U. von, Maryja w tajemnicy Kościoła, Kraków 2007. 
14. Rosik M., Obecność Maryi w narodzinach Kościoła w świetle Nowego Testamentu, „Salvatoris Mater” 2007, 9/3/4, s. 11-28.

15. Scheingraber S., Aufbruch zur „verbeulten Kirche“. Die Ekklesiologie von Papst Franziskus, Würzburg 2019.

16. Życiński W., Jaka mariologia na polskiej drodze maryjnej dzisiaj, [w:] Na polskiej drodze maryjnej, red. A. Gąsior, J. Królikowski, Częstochowa - Pasierbiec 2007, s. 139-151. 